Article

\title{
Fe-Ni-P-S Melt Pockets in Elga IIE Iron Meteorite: Evidence for the Origin at High-Pressures Up to $20 \mathrm{GPa}^{\dagger}$
}

\author{
Konstantin D. Litasov ${ }^{1,2, *(D)}$, Svetlana N. Teplyakova ${ }^{3}$, Anton Shatskiy ${ }^{1,2}$ \\ and Konstantin E. Kuper 4

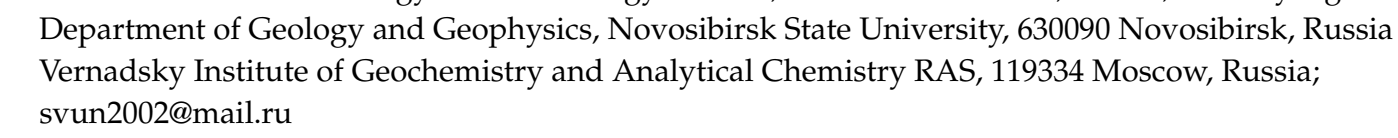

Received: 31 July 2019; Accepted: 3 October 2019; Published: 7 October 2019

\begin{abstract}
Here we report new data on high-pressure microstructures in Elga group IIE iron meteorites, made of solidified Fe-Ni-P-S melt pockets and microcrystalline aggregates, which could be formed only at high pressures and temperatures according to the experimental data. The bulk composition of the melt pockets and crystals correspond to the $\mathrm{Fe}_{3} \mathrm{P}-\mathrm{Fe}_{3} \mathrm{~S}$ solid solution with the closure of an immiscibility gap at pressures near $20 \mathrm{GPa}$ in static experiments. Some other melt pockets fit with the $\mathrm{Fe}_{2} \mathrm{~S}-\mathrm{Fe}_{2} \mathrm{P}$ compositions, which could also correspond to high pressures and temperatures. The results suggest a late shock episode during the formation of the IIE iron parent body, which may be prior or due to the final disruption that caused the meteorite arrival to Earth. It also has an important implication to the shock features in other meteorites, such as ureilite.
\end{abstract}

Keywords: iron meteorite; shock metamorphism; high-pressure phases; phosphide; sulfide

\section{Introduction}

The shock-melt veins and high-pressure minerals are common in chondritic and martian meteorites and rare in other types of meteorites, including lunar samples [1,2]. Shock-induced deformations, melt pockets, and other microstructural features are also common for iron meteorites [3-5]. However, there have been scarce findings of high-pressure minerals, including stishovite in group IVA iron meteorite Muonionalusta [6], $(\mathrm{Fe}, \mathrm{Ni})_{2} \mathrm{P}$-allabogdanite in anomalous Ni-rich ataxites Onello, Santa Catharina, and Barbianello [7-9] and tuite in IIE iron Elga [10].

Elga represents IIE iron meteorite group, which contains $5-20 \%$ of silicate inclusions in the metallic matrix [10-18]. In the studied samples, the metal part includes kamacite with rare taenite inclusions and abundant zones with plessite textures. Large rounded troilite and irregular schreibersite $(\mathrm{Fe}, \mathrm{Ni})_{3} \mathrm{P}$ inclusions are abundant. Rounded or irregular shape silicate inclusions caould be divided into three major types, including (1) silicate glass with abundant large $\mathrm{Cr}$-diopside and minor small enstatite crystals; (2) silicate glass with tiny quenched crystals of enstatite, plagioclase, and cristobalite; (3) silicate/phosphate inclusions with liquid immiscibility. One additional group of inclusions, which consist of granular olivine, Cr-diopside, and enstatite were reported by Osadchii et al. [14]. The major phases of silicate inclusions are $\mathrm{Cr}$-diopside and enstatite; accessory minerals are represented by chromite, ilmenite, rutile, armalcolite, aenigmatite, and phosphate minerals [16-18]. Solidified 
shock melt is represented by an immiscible fine-grained mixture of silicate-phosphate and metallic parts $[10,13,17]$. The metal captured to shocked zone appears as Fe-Ni-P or Fe-Ni-P-S-bearing symplectite-like or cryptocrystalline melt pockets. Tuite was identified by Raman spectroscopy in shock-melted zones at the boundary of silicate inclusions [10].

Here for the first time, we report new evidence for high-pressure microstructures in Elga, made of Fe-Ni-P-S aggregates, which could be formed only at high pressures and temperatures according to the experimental phase diagrams $[19,20]$.

\section{Materials and Methods}

The Elga meteorite was found in 1959 in Yakutia (Russia) [11,17]. The main mass of $23 \mathrm{~kg}$ is in the Central Siberian Geological Museum, Novosibirsk. We studied six polished slices of the meteorite from the working collection, 5-7 g each. Polished sample sections (Figure 1) were characterized using a Tescan MYRA 3 LMU scanning electron microscope coupled with an INCA energy-dispersive X-ray microanalysis system 450 equipped with the liquid nitrogen-free Large area EDS X-Max-80 Silicon Drift Detector (Oxford Instruments) at the Sobolev Institute of Geology and Mineralogy, Novosibirsk. The energy-dispersive X-ray spectra (EDS) were collected by sharp 1-2 $\mu \mathrm{m}$ or scattered over a sample area electron beam at $20 \mathrm{kV}$ accelerating voltage and $1 \mathrm{nA}$ beam current. Counting times for spectra collection were 30-60 s. No beam damage or change in measured composition with time was observed when using the current setting. The EDS spectra were optimized for the quantification using the standard XPP (exponential model of Pouchou and Pichoir matrix correction) procedure included in the INCA Energy 450 software. Calibrated EDS spectra from the used device were reported to be of the same or even better quality as the wavelength dispersive analysis in many recent work [21-23]. In addition to standard minerals, oxides, and metals, mentioned in these papers, we used synthetic $\mathrm{Fe}_{3} \mathrm{P}, \mathrm{Ni}_{3} \mathrm{P}$, and $\mathrm{FeS}$ as internal standards for EDS analyses.

The crystal structure of the single crystal and nanocrystalline $(\mathrm{Fe}, \mathrm{Ni})_{3}(\mathrm{P}, \mathrm{S})$ was confirmed using the Electron Backscatter Diffraction (EBSD) of the chemo-mechanically polished plates. Colloidal silica was used for the final sample polishing. The EBSD data were collected on a Hitachi S-3400 N scanning electron microscope equipped with an Oxford Instruments HKL detector with an accuracy of misorientations of $0.5-1.0^{\circ}$ at $20 \mathrm{kV}$ accelerating voltage, $8 \mathrm{nA}$ beam current, $15.5 \mathrm{~mm}$ working distance, and $70^{\circ}$ tilt angle. The Kikuchi patterns of individual points were automatically indexed by the Oxford data collection software. The spatial resolution of EBSD was less than $1 \mu \mathrm{m}$.

\section{Results}

Schreibersite and troilite in Elga often form rim zones around silicate inclusions and located in fractures along the metal sub-grains (Figure 1). Representative compositions of the primary phases are shown in Table 1. In the fractures, schreibersite and troilite are severely crumpled and re-melted

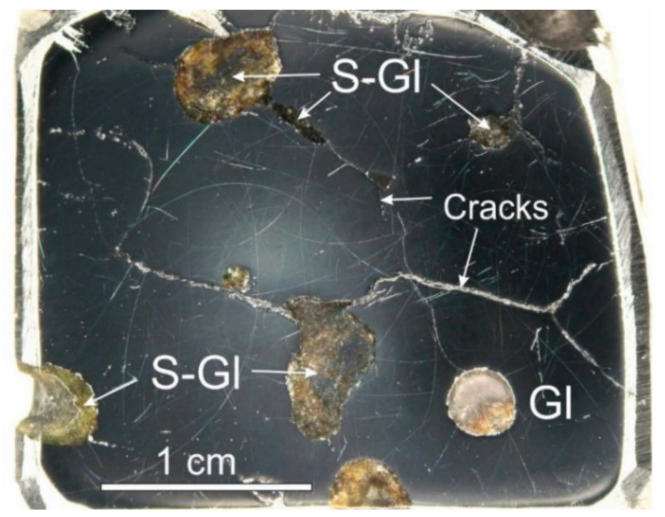

Figure 1. Example of a polished fragment of Elga IIE iron meteorite. S-GL—silicate + glass inclusions, Gl-felsic glass inclusion. 
Table 1. Average composition (wt.\%) of primary minerals from the Elga meteorite.

\begin{tabular}{cccccccccc}
\hline Mineral & $n$ & Cr & Fe & Co & Ni & $\mathbf{P}$ & S & O & Total \\
\hline Kamacite & 124 & & 91.91 & 0.77 & 7.08 & 0.17 & & & 99.93 \\
SD & & & 2.58 & 0.14 & 0.62 & 0.13 & & & \\
Taenite & 60 & & 76.22 & 0.48 & 23.10 & 0.05 & & & 99.85 \\
SD & & & 3.25 & 0.15 & 3.31 & 0.05 & & & \\
Schreibersite & 56 & & 61.16 & 0.41 & 22.66 & 15.35 & 0.02 & 0.22 & 99.82 \\
SD & & & 2.49 & 0.12 & 2.45 & 0.73 & 0.01 & 0.21 & \\
Troilite & 60 & 0.13 & 63.08 & 0.01 & & 0.07 & 36.25 & & 99.54 \\
SD & & 0.07 & 1.17 & 0.01 & & 0.05 & 1.24 & & \\
\hline
\end{tabular}

$n-$ number of analyses. SD—standard deviation.

Various Fe-Ni-P and Fe-Ni-P-S melt pockets can be distinguished in the fractures and near silicate inclusions (Figures 2-7). In this paper, we consider only Fe-Ni-P-S aggregates. They can be subdivided into the following types according to their bulk compositions: (a) FN3-corresponding to stoichiometric $(\mathrm{Fe}, \mathrm{Ni})_{3}(\mathrm{P}, \mathrm{S})$; (b) FN2-corresponding to stoichiometric $(\mathrm{Fe}, \mathrm{Ni})_{2}(\mathrm{P}, \mathrm{S})$; (c) FN3-Ox-partially oxidized $(\mathrm{Fe}, \mathrm{Ni})_{3}(\mathrm{P}, \mathrm{S}) ;(\mathrm{d}) \mathrm{FN2}-\mathrm{Ox}$-partially oxidized $(\mathrm{Fe}, \mathrm{Ni})_{2}(\mathrm{P}, \mathrm{S}) ;(\mathrm{e}) \mathrm{FNX}$-other compositions with the $\mathrm{P}$ and $\mathrm{S}$ contents deviating from stoichiometric proportions; and (f) FNX-Ox - partially oxidized $(\mathrm{Fe}, \mathrm{Ni})_{\mathrm{n}}(\mathrm{P}, \mathrm{S})$ (Table 2 and Table S1 in Supplementary Materials).
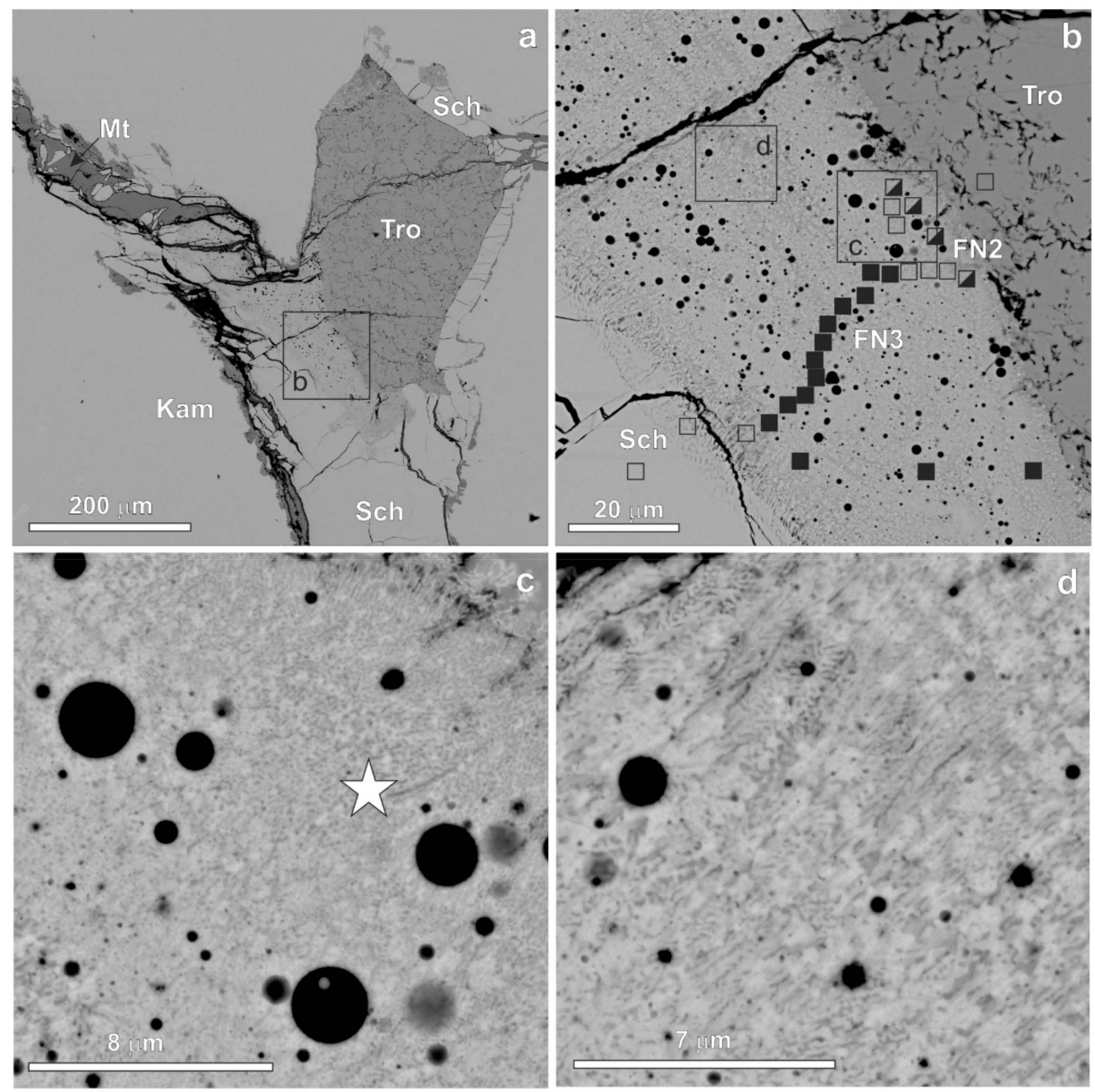

Figure 2. Zone of high-pressure $(\mathrm{Fe}, \mathrm{Ni})_{3}(\mathrm{P}, \mathrm{S})$ between schreibersite ( $\mathrm{Sch}$ ) and troilite (Tro) (Table S2). Squares show the positions of the EDS analyses: filled-FN3; half-filled-FN2, empty—others. The star shows the position of the EBSD pattern. Kam—kamacite; Mt—magnetite. 
Table 2. Average compositions (wt \%) of Fe-Ni-P-S melt pockets and crystalline aggregates from the Elga IIE iron meteorite.

\begin{tabular}{|c|c|c|c|c|c|c|c|c|c|c|}
\hline \multirow{3}{*}{$\begin{array}{c}\begin{array}{c}\text { Type } \\
\text { Site }\end{array} \\
\mathrm{Fe}\end{array}$} & \multirow{2}{*}{\multicolumn{2}{|c|}{$\begin{array}{c}\text { FN3 } \\
14-15\end{array}$}} & \multirow{2}{*}{\multicolumn{2}{|c|}{$\begin{array}{c}\text { FN3 } \\
23-24\end{array}$}} & \multirow{2}{*}{\multicolumn{2}{|c|}{$\begin{array}{c}\text { FN3-Ox } \\
13\end{array}$}} & \multirow{2}{*}{\multicolumn{2}{|c|}{$\begin{array}{c}\text { FN3-Cryst } \\
13\end{array}$}} & \multirow{2}{*}{\multicolumn{2}{|c|}{$\begin{array}{c}\text { FN2 } \\
15,19\end{array}$}} \\
\hline & & & & & & & & & & \\
\hline & 68.79 & 0.63 & 62.78 & 2.88 & 62.78 & 2.31 & 66.85 & 0.96 & 66.19 & 0.94 \\
\hline Co & 0.55 & 0.07 & 0.49 & 0.13 & 0.66 & 0.16 & 0.50 & 0.09 & 0.45 & 0.07 \\
\hline $\mathrm{Ni}$ & 13.79 & 0.39 & 19.60 & 2.61 & 15.85 & 0.55 & 15.04 & 0.79 & 11.16 & 0.48 \\
\hline $\mathrm{P}$ & 10.31 & 0.50 & 9.26 & 0.10 & 10.15 & 0.39 & 11.06 & 0.11 & 5.44 & 0.20 \\
\hline$S$ & 4.88 & 0.55 & 6.15 & 0.18 & 4.69 & 0.21 & 4.36 & 0.15 & 16.07 & 0.32 \\
\hline $\mathrm{O}$ & 1.13 & 0.14 & 1.18 & 0.11 & 5.65 & 2.38 & 1.53 & 0.06 & 0.44 & 0.49 \\
\hline Total & 99.45 & 0.55 & 99.46 & 0.72 & 99.77 & 0.71 & 99.33 & 0.23 & 99.74 & 0.23 \\
\hline \multicolumn{11}{|c|}{ Atomic ratios per 12 atoms. $\mathrm{M}=\mathrm{Fe}+\mathrm{Ni}+\mathrm{Co}$} \\
\hline $\mathrm{Fe}$ & 7.537 & & 6.892 & & 7.178 & & 7.349 & & 6.905 & \\
\hline $\mathrm{Ni}$ & 1.438 & & 2.048 & & 1.725 & & 1.573 & & 1.107 & \\
\hline Co & 0.057 & & 0.051 & & 0.071 & & 0.052 & & 0.045 & \\
\hline $\mathrm{P}$ & 2.037 & & 1.832 & & 2.093 & & 2.192 & & 1.023 & \\
\hline$S$ & 0.931 & & 1.177 & & 0.933 & & 0.834 & & 2.919 & \\
\hline M & 9.032 & & 8.991 & & 8.974 & & 8.974 & & 8.057 & \\
\hline $\mathrm{P}+\mathrm{S}$ & 2.968 & & 3.009 & & 3.026 & & 3.026 & & 3.943 & \\
\hline Type & \multicolumn{2}{|c|}{ FN3 } & \multicolumn{2}{|c|}{ FNX } & \multicolumn{3}{|c|}{ Fe-mix } & \multicolumn{3}{|c|}{ Fe-mix } \\
\hline Site & \multicolumn{2}{|c|}{$9,23 a$} & \multicolumn{2}{|c|}{$8-9,23 a$} & \multicolumn{3}{|c|}{27} & \multicolumn{3}{|c|}{28} \\
\hline $\mathrm{Fe}$ & 68.18 & 0.41 & \multicolumn{2}{|c|}{81.44} & 0.74 & 68.85 & 1.33 & 77.79 & \multicolumn{2}{|r|}{1.02} \\
\hline Co & 0.56 & 0.11 & \multicolumn{2}{|c|}{0.77} & 0.09 & 0.54 & 0.11 & 0.70 & \multicolumn{2}{|r|}{0.07} \\
\hline $\mathrm{Ni}$ & 14.88 & 0.06 & \multicolumn{2}{|c|}{10.64} & 0.45 & 15.47 & 1.65 & 11.49 & \multicolumn{2}{|r|}{0.43} \\
\hline $\mathrm{P}$ & 6.53 & 0.30 & \multicolumn{2}{|c|}{3.60} & 0.20 & 8.18 & 1.40 & 4.71 & \multicolumn{2}{|r|}{0.41} \\
\hline$S$ & 9.00 & 0.27 & \multicolumn{2}{|c|}{3.29} & 0.24 & 5.50 & 1.71 & 4.08 & \multicolumn{2}{|r|}{0.69} \\
\hline $\mathrm{O}$ & 0.91 & 0.21 & \multicolumn{2}{|c|}{0.59} & 0.13 & 0.98 & 0.08 & 0.72 & \multicolumn{2}{|r|}{0.11} \\
\hline Total & 100.06 & 0.48 & & & 0.36 & 99.53 & 0.56 & 99.49 & & 0.10 \\
\hline & & & & nic rati & per $12 a$ & $m s . M=$ & $e+N i$ & & & \\
\hline $\mathrm{Fe}$ & 7.415 & & & & & 7.620 & & 8.891 & & \\
\hline $\mathrm{Ni}$ & 1.540 & & & & & 1.630 & & 1.249 & & \\
\hline Co & 0.058 & & & & & 0.056 & & 0.076 & & \\
\hline $\mathrm{P}$ & 1.281 & & & & & 1.633 & & 0.970 & & \\
\hline$S$ & 1.706 & & & & & 1.061 & & 0.813 & & \\
\hline M & 9.013 & & & & & 9.306 & & 10.216 & & \\
\hline $\mathrm{P}+\mathrm{S}$ & 2.987 & & & & & 2.694 & & 1.784 & & \\
\hline
\end{tabular}

FN3 appears as a micro- or nanocrystalline mixture of two or three phases at the boundary between schreibersite and troilite, where melt pockets could form zoned patterns with FN2 near troilite, intermediate compositions between FN2 and FN3 (Figure 2 and Table S2), and FN3 aggregates partially contaminated by metal. In the latter, FN3 is represented by cryptocrystalline zones surrounded by FNX (Figure 3 and Table S1).

FN3 can also form crystal-like aggregates surrounded by a partially oxidized quenched zone with the same composition (Figure 4). Preliminary transmission electron microscope data indicate the nanocrystalline nature of this crystal-like aggregate. It consists of 10-20 nm crystals representing a mixture of S-containing schreibersite and S-bearing area with unknown composition. 

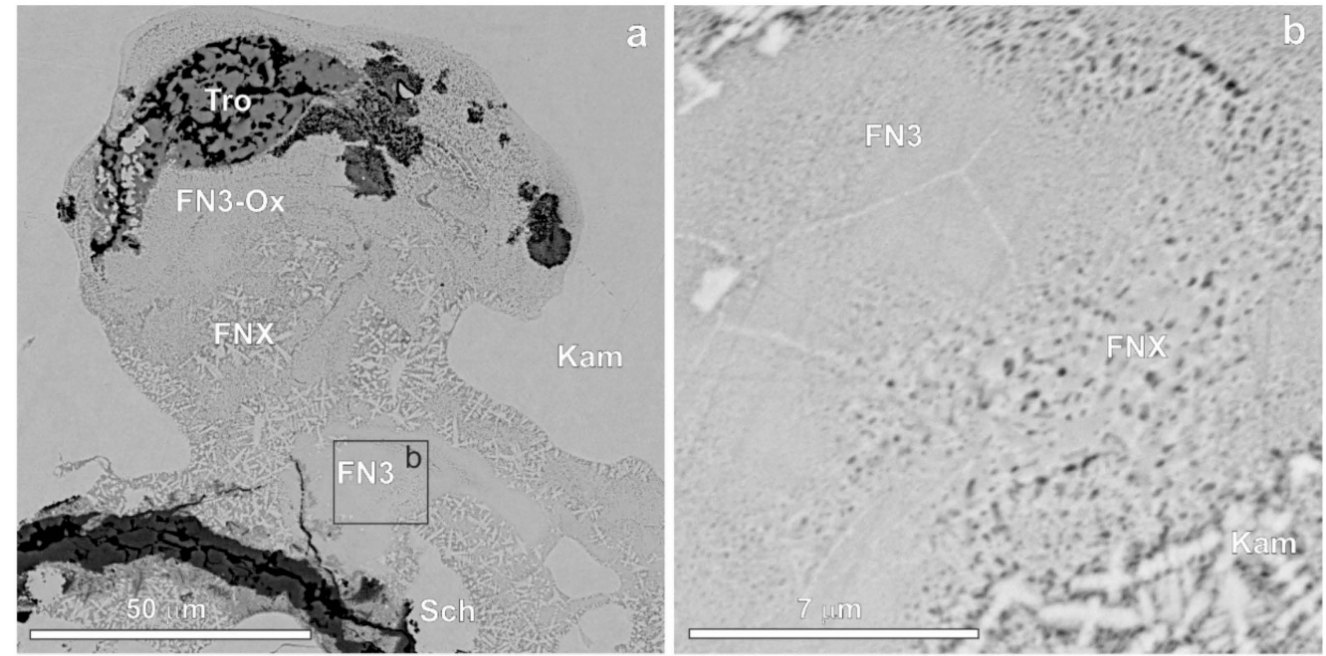

Figure 3. Nanocrystalline $(\mathrm{Fe}, \mathrm{Ni})_{3}(\mathrm{P}, \mathrm{S})$ zones surrounded by non-stoichiometric FNX with clear dendrites of (Fe,Ni)-metal (Site 10-12 in Table S1).

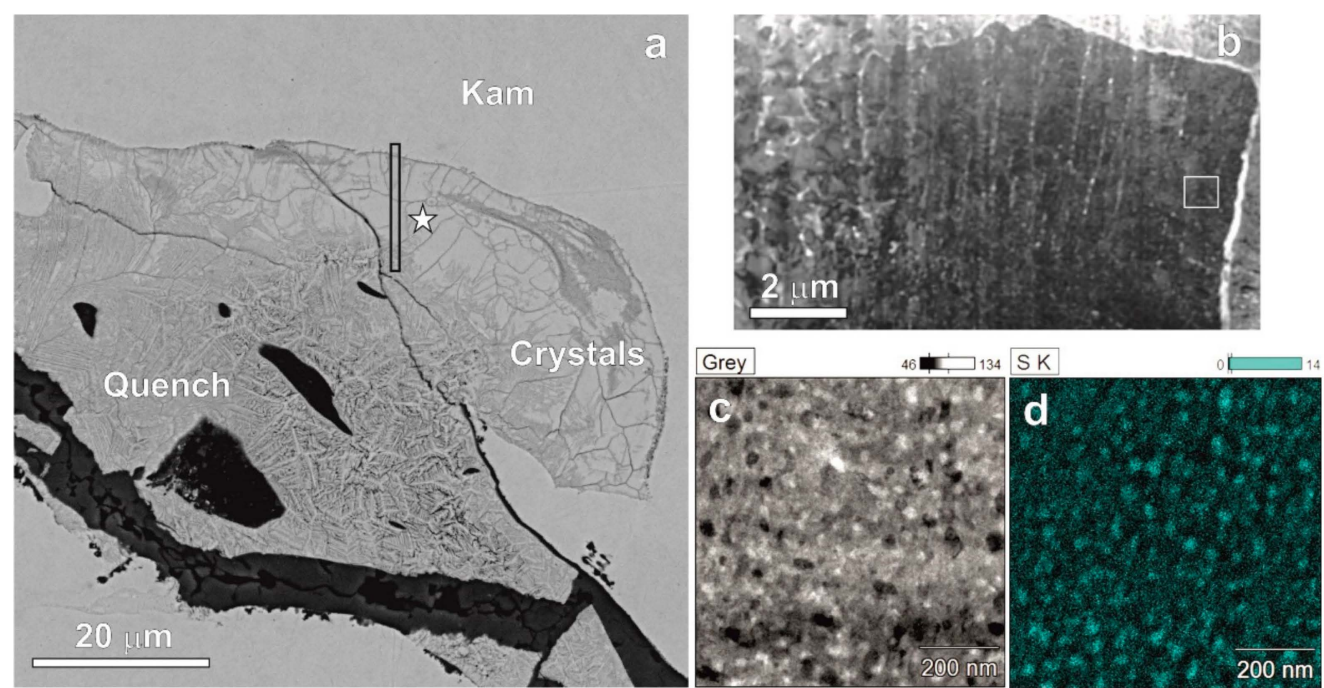

Figure 4. Crystal-like FN3 aggregate with average composition $\left(\mathrm{Fe}_{2.45} \mathrm{Ni}_{0.52} \mathrm{Co}_{0.02}\right)_{2.99}\left(\mathrm{P}_{0.73} \mathrm{~S}_{0.28}\right)_{1.01}$ (a) coexisting with quenched oxidized FN3 aggregates (Site 13 in Table S1). Star shows position of EBSD pattern. Bar shows location of focused ion beam film presented in (b). (c) and (d) secondary electron image and elemental map for sulfur in the area shown by square in (b). (b-d) are based on our preliminary transmission electron microscope data.

Another appearance of FN3 is connected with quenched textures, which may have crystallized from the melt (Figure 5a). Finally, it can form interstitial zones in non-stoichiometric mixtures with (Fe,Ni)-metal (Figure $5 b, c)$. The composition of FN3 varies from $(\mathrm{Fe}, \mathrm{Ni})_{3} \mathrm{P}_{0.8} \mathrm{~S}_{0.2}$ to $(\mathrm{Fe}, \mathrm{Ni})_{3} \mathrm{P}_{0.4} \mathrm{~S}_{0.6}$ (Figure 6, Table 2). The EBSD analyses on nanocrystalline aggregates of FN3 and single crystal-like areas of FN3 indicate the presence of a phase with the $I \overline{4}$ schreibersite-type structure [24] and mean angular deviation (MAD) of measurements between $0.1^{\circ}$ and $0.3^{\circ}$ (Figure 7). No troilite or kamacite could be identified in such aggregates suggesting the presence of crystalline FN3 or a nanocrystalline mixture with the FN3 composition. In Figures 2 and 4, we could recognize two phases in the BSE images of Fe-Ni-P-S aggregates. It is obvious that one needs to add 20 to $60 \mathrm{~mol} \%$ (Fe,Ni)-metal to fit the compositions of FN3 (Figure 6), which is not the case. The FN3 compositions were also observed in some microcrystalline Fe-Ni-P-S aggregates with a grain size of 0.1-2.0 $\mu \mathrm{m}$, where we could identify schreibersite, troilite, and kamacite (e.g., Figure 5a). In this case, it is difficult to suggest that this is a 
former high-pressure FN3 phase; however, a close resemblance to the stoichiometric compositions may not be accidental.

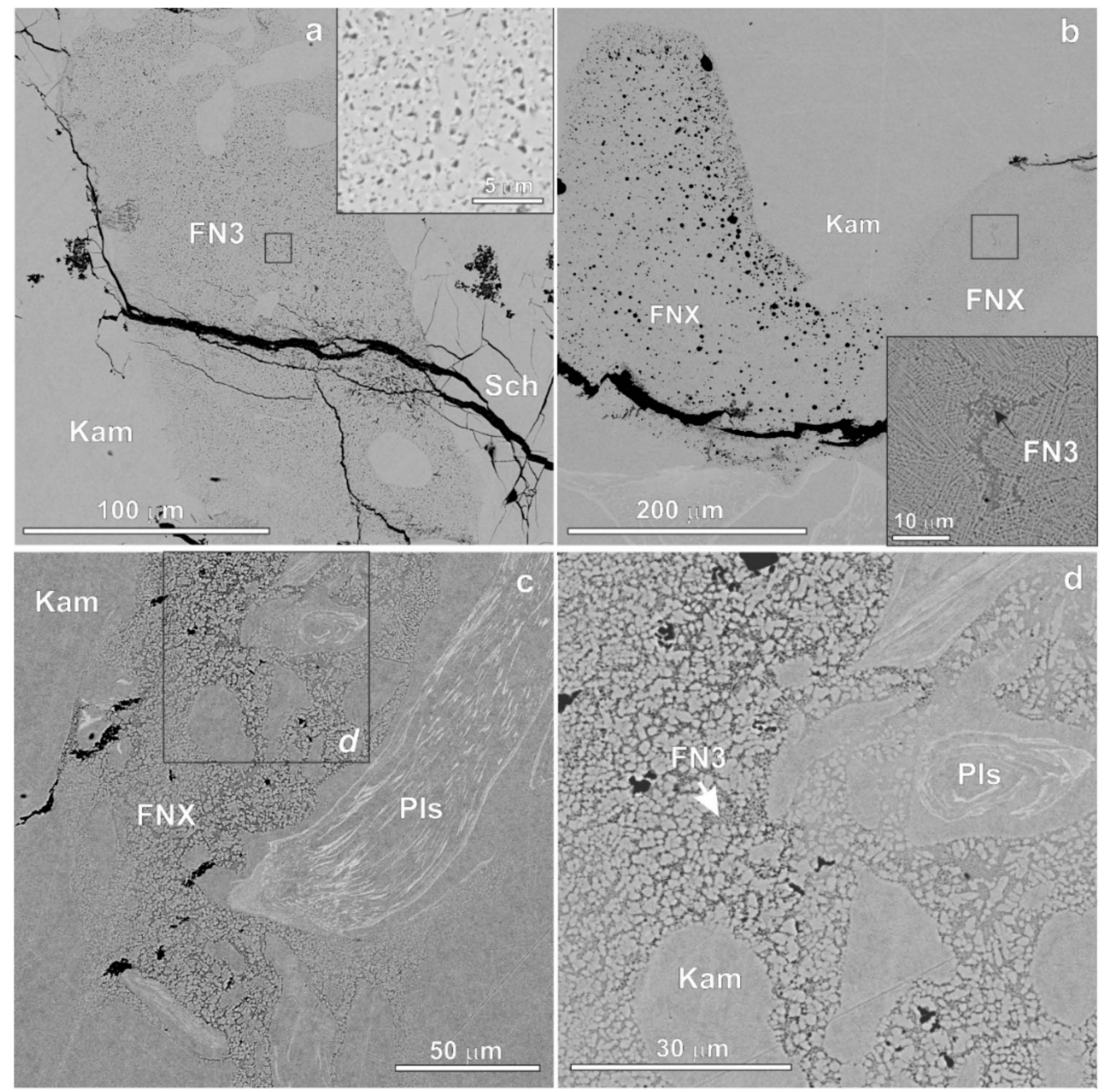

Figure 5. Fe-Ni-P-S aggregates from Elga meteorite. (a) Sites 14-15, FN3 represented by quench aggregates of three phases, schreibersite (Sch, grey), troilite (dark), and kamacite (Kam, white); (b) Sites 8-9, 23a, interstitial FN2 aggregate in FNX nonstoichiometric matrix; (c) Site 28, zone of deformation of plessite with mixed FNX aggregates, some areas shown in (d) have compositions corresponding to FN3. Pls-plessite. Black squares show the position of the inserts. See Table S1 for chemical compositions.

FN2 form micro- and nanocrystalline mixtures of dendritic crystals and appears near the boundary with troilite along with FN3 aggregates (Figure 2) or as interstitial pockets in the non-stoichiometric FNX zones (Figure 5b). Sometimes FN2 looks like a mechanical mixture of troilite and schreibersite crystals (Figure 8). Its composition varies from $(\mathrm{Fe}, \mathrm{Ni})_{2} \mathrm{P}_{0.5} \mathrm{~S}_{0.5}$ to $(\mathrm{Fe}, \mathrm{Ni})_{2} \mathrm{P}_{0.2} \mathrm{~S}_{0.8}$ (Figure 6, Table 2), and it is easy to identify troilite microcrystals by EBSD measurements.

The oxidized regions of FN3 and FN2 appear due to partial oxidation of the metal or alloy with the formation of magnetite or trevorite (Figure 9, Table S3). In this case, the stoichiometry could remain the same or slightly deviate from the original FN3 or FN2 (Figure 6). The composition of the various FNX and FNX-Ox aggregates deviates from stoichiometric FN3 and FN2 due to the admixture of the metallic phase (Figure 6). Some of them correspond to the composition of the miscible Fe-Ni-P-S melts (Figures 5 and 6 ) and could be formed at low to zero pressures [25,26]. 


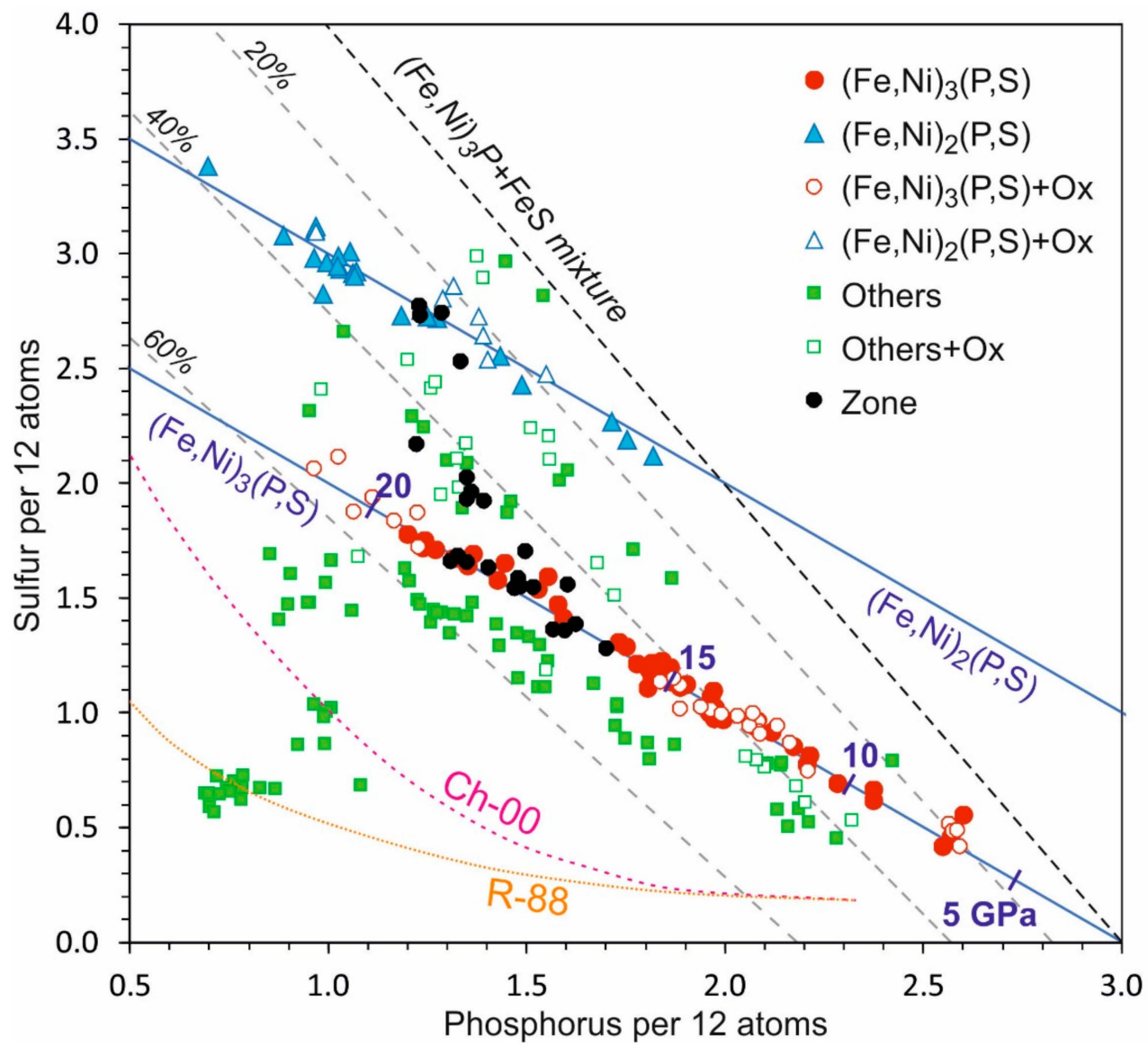

Figure 6. Phosphorus vs, sulfur contents in $(\mathrm{Fe}, \mathrm{Ni})_{3}(\mathrm{P}, \mathrm{S})$ melt pockets from Elga meteorite. Ox-partially oxidized melt pockets. Others correspond to intermediate non-stoichiometric FNX compositions. "Zone" shows the compositional variation of $\mathrm{Fe}-\mathrm{Ni}-\mathrm{P}-\mathrm{S}$ alloy from schreibersite to troilite (see Figure 2 and Table S2). Pressure values in GPa correspond to maximum $\mathrm{S}$ solubility in $\mathrm{Fe}_{3} \mathrm{P}_{1-\mathrm{x}} \mathrm{S}_{\mathrm{x}}$ alloys [20]. Black dashed line shows compositions of mechanical mixture between schreibersite and troilite. Grey dashed lines are same with an addition of 20,40, and $60 \mathrm{~mol}$ \% of (Fe,Ni)-metal. Dotted lines show the limit of liquid immiscibility in the Fe-P-S system after Raghavan [25] (R-88) and Chabot and Drake [26] (Ch-00).

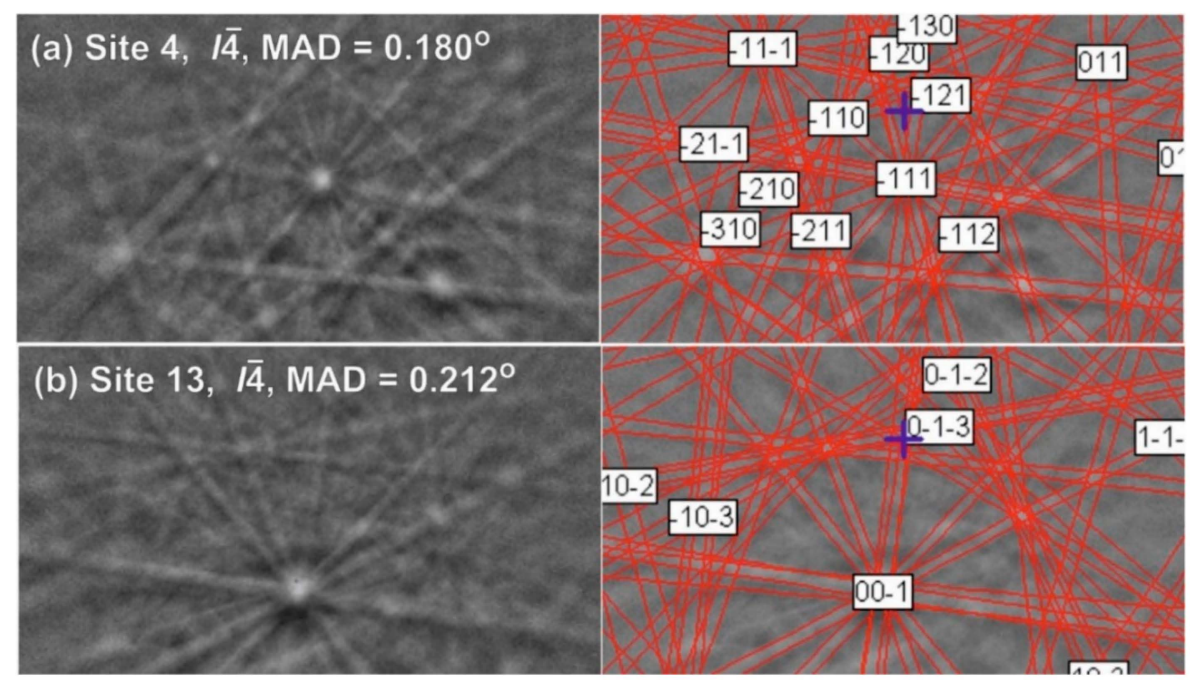

Figure 7. Representative EBSD patterns from $(\mathrm{Fe}, \mathrm{Ni})_{3}(\mathrm{P}, \mathrm{S})$, indexed with the schreibersite-type structure shown in Figures 2 and 4. 

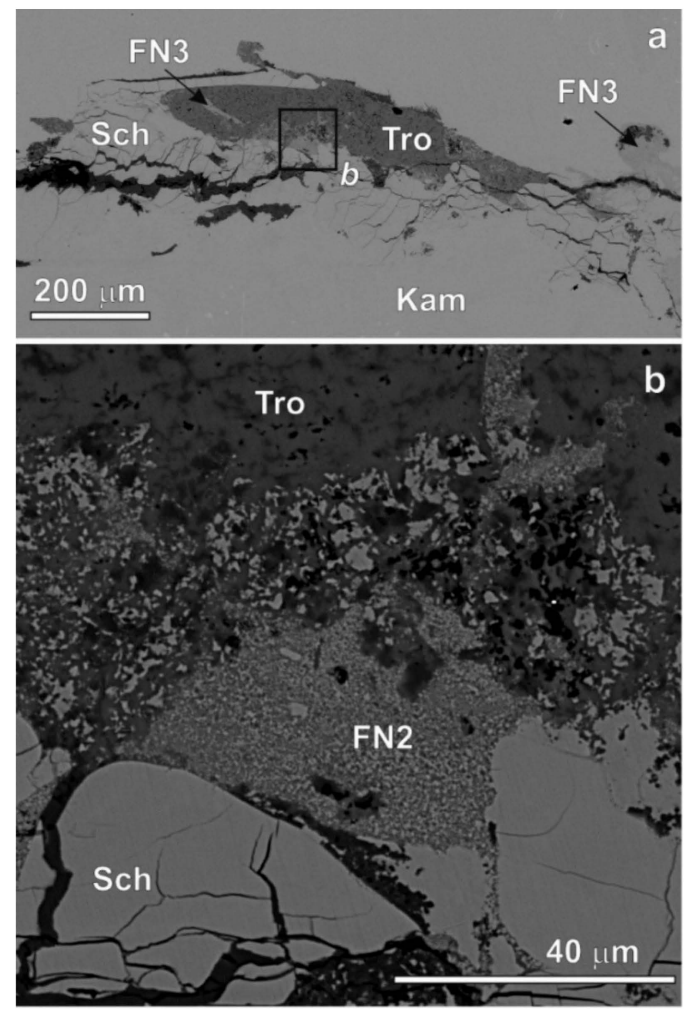

Figure 8. Sites 15 and 19, FN2 at the boundary between troilite (Tro) and schreibersite (Sch). Troilite contains nanocrystalline inclusions of FN3. See Table S1 for chemical compositions (Site 19).

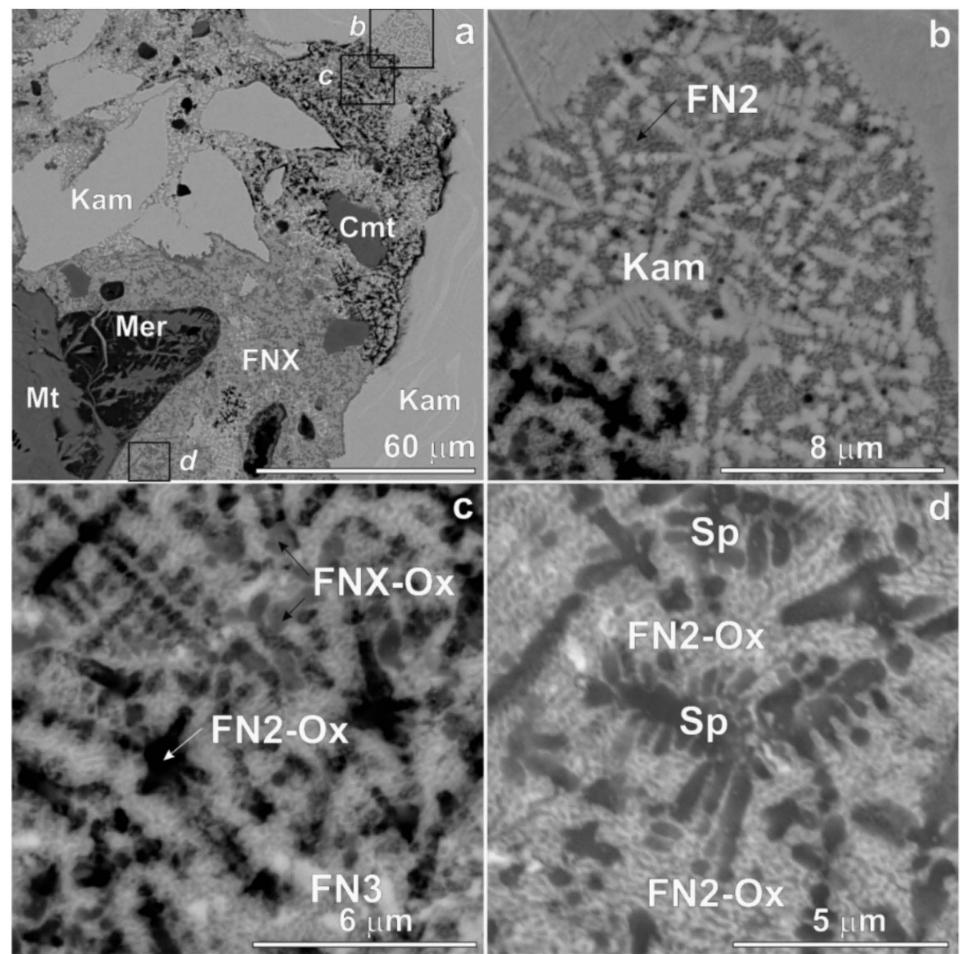

Figure 9. Oxidized quenched textures of Fe-Ni-P-S aggregates (FNX) near a crack in kamacite (Kam) matrix. (a) Site 15, general view, (b-d) enlarged areas. (b) Site 16, intergrowth of kamacite and FN2; (c) Site 17, intergrowth of FN3 (white), FN2-Ox (black) and FNX-Ox (grey). (d) Site 18, intergrowth of FN2-Ox and spinel. Cmt-chromite, Mer-merrillite; Mt-magnetite; Sp-trevorite-like spinel. See Table S3 for chemical compositions. 


\section{Discussion}

\subsection{High-Pressure Origin of $(\mathrm{Fe}, \mathrm{Ni})_{3}(\mathrm{P}, \mathrm{S})$}

$\mathrm{Fe}_{3} \mathrm{P}$ and $\mathrm{Fe}_{3} \mathrm{~S}$ are isostructural at high pressure and form a complete solid solution at $\mathrm{P}>20 \mathrm{GPa}$ [19]. This may indicate partial solubility of sulfur in $\mathrm{Fe}_{3} \mathrm{P}$ at lower pressures. $\mathrm{Gu}$ et al. [20] calibrated the pressure dependence of sulfur solubility in tetragonal $\mathrm{Fe}_{3} \mathrm{P}$ and argued that it could be used as a pressure marker for natural $\mathrm{Fe}-\mathrm{Ni}$ alloys containing $\mathrm{P}$ and $\mathrm{S}$. They predicted that this solid solution could be found in meteorites, as it is the case in the studied Elga sample. We plotted calibration of Gu et al. [20] in Figure 6 and argue that most FN3 crystals and nanocrystalline aggregates correspond to pressures of 10-20 GPa according to the static high-pressure experiments. This calibration may be slightly distorted by the addition of $\mathrm{Ni}$ to the system since $\mathrm{Ni}_{3} \mathrm{~S}$, isostructural with schreibersite, appears at pressures about $5 \mathrm{GPa}$ [27]. There is no experimental data to evaluate the pressure effect of $\mathrm{Ni}$ substitution for $\mathrm{Fe}$ in $\mathrm{Fe}_{3}(\mathrm{P}, \mathrm{S})$. However, assuming a linear relationship between the stability pressures of $\mathrm{Ni}_{3} \mathrm{~S}$ and $\mathrm{Fe}_{3} \mathrm{~S}$, we can suggest that 20 mol. \% of $\mathrm{Ni}$ in $(\mathrm{Fe}, \mathrm{Ni})_{3}(\mathrm{P}, \mathrm{S})$ would reduce the estimated pressures for 2-3 GPa [28]. Thus, the pressure estimations for the FN3 aggregates would be at least 7-17 GPa. Previous findings of tuite, which is stable at pressures above $12 \mathrm{GPa}[29,30]$ in the shocked zones of silicate inclusions in Elga are consistent with the data for the FN3 aggregates.

The origin of FN2 is presently not clear. Gu et al. [20] reported that $\mathrm{Fe}_{2} \mathrm{P}$ dissolves $\mathrm{S}$ at high pressures. However, quantitative data on the $\mathrm{S}$ solubility in $\mathrm{Fe}_{2} \mathrm{P}$ as a function of pressure are not yet available. The close textural relations between FN3 and FN2 in the Elga meteorite and the lack of stable sulfides with the $\mathrm{Fe}_{2} \mathrm{~S}$ stoichiometry in the studied pressure range [31,32] indicate the possibility of a high-pressure origin for FN2. In this regard, the stoichiometric composition of these aggregates is unlikely to be accidental (Figure 6).

\subsection{The Implication of the Results for Putative Impact Events during the Formation of IIE Iron Meteorites and Ureilites}

Silicate-bearing iron meteorites are important for understanding the early evolutionary processes in the solar system that affected planetesimals and small bodies. Group IIE iron meteorites often contain $5-20 \%$ of silicates as inclusions, varying in composition from mafic to felsic and ultrafelsic. These inclusions show genetic relations to $\mathrm{H}$-chondrites, as revealed by their isotopic and geochemical characteristics $[33,34]$. The origin of IIE irons with fractionated (non-chondritic) silicate inclusions, such as Elga meteorite, is best explained by a model of disruption and reassembly of partially molten asteroids with complex impact history, when some impact events are related to the formation of silicate inclusions and some to deformation and recrystallization along narrow zones in meteorites [34]. The formation of high-pressure minerals on a microscopic scale could be related to the late impacts. However, presumable extremely high-pressures exceeding 15 GPa recorded by Fe-Ni-P-S aggregates in the Elga indicate that the impact events were almost as intense as during the formation of high-pressure minerals in chondrites, where pressures exceeding 25 GPa were recorded [2].

S-bearing inclusions $(\mathrm{S} /(\mathrm{S}+\mathrm{P}) \approx 0.12)$ with a bulk composition close to the $(\mathrm{Fe}, \mathrm{Ni})_{3}(\mathrm{~S}, \mathrm{P})$ stoichiometry were found inside the diamond grains in Almahata Sitta ureilite [28]. These inclusions are interpreted to have been recrystallized to nanocrystalline aggregates of troilite, kamacite, and schreibersite by decompression. The authors relate the origin of these inclusions to pressures above $20 \mathrm{GPa}$ inside the ureilite parent body. We show that these phases could be formed by the shock processes and do not support the idea about the origin of ureilites and their diamonds under the static high-pressure and high-temperature conditions. In our opinion, the FN3 aggregates in ureilitic diamonds, as well as diamonds themselves, were formed dynamically during a strong disruption impact event. This strong impact could cause the formation of enlarged diamond crystals (up to $100 \mu \mathrm{m}$ ) that exceed the normal size of impact diamond crystals $(<5 \mu \mathrm{m})$ and is considered to be important evidence for the formation of ureilite diamonds in the deep interior of the ureilite parent body [35]. 
Supplementary Materials: The following are available online at http:/www.mdpi.com/2075-163X/9/10/616/s1, Table S1: Representative compositions (wt \%) of Fe-Ni-P-S aggregates from the Elga IIE iron meteorite. Table S2: Composition (wt \%) of Fe-Ni-P-S alloys across the shocked boundary between schreibersite and troilite. Table S3: Detailed analyses (wt \%) of Fe-Ni-P-S S dendritic aggregates subjected to oxidation or mixed with oxidized materials.

Author Contributions: K.D.L. and S.N.T. designed the study, K.D.L. and A.S. prepared and analyzed samples, K.E.K. and K.D.L. performed EBSD measurements. All the authors contributed to the text and figures.

Funding: This research was funded by the Russian Science Foundation, grant number 17-17-01177.

Acknowledgments: We thank the anonymous reviewers for their valuable comments and $\mathrm{F}$. Wu for editorial handling.

Conflicts of Interest: The authors declare no conflict of interest.

\section{References}

1. Gillet, P.; El Goresy, A. Shock events in the Solar System: The message from minerals in terrestrial planets and asteroids. Annu. Rev. Earth Planet. Sci. 2013, 41, 257-285. [CrossRef]

2. Tomioka, N.; Miyahara, M. High-pressure minerals in shocked meteorites. Meteorit. Planet. Sci. 2017, 52, 2017-2039. [CrossRef]

3. Bevan, A.W.R.; Kinder, J.; Axon, H.J. A metallographic study of the iron meteorite Verkhne Dnieprovsk (BM 51183). Mineral. Mag. 1979, 43, 149-154. [CrossRef]

4. Buchwald, V.F. Handbook of Iron Meteorites: Their History, Distribution, Composition, and Structure; University of California Press: Berkeley, CA, USA, 1975.

5. Olsen, E.; Davis, A.; Clarke, R.S., Jr.; Schultz, L.; Weber, H.W.; Clayton, R.; Mayeda, T.; Jarosewich, E.; Sylvester, P.; Grossman, L. Watson: A new link in the HE iron chain. Meteoritics 1994, 29, 200-213. [CrossRef]

6. Holtstam, D.; Broman, C.; Söderhielm, J.; Zetterqvist, A. First discovery of stishovite in an iron meteorite. Meteorit. Planet. Sci. 2003, 38, 1579-1583. [CrossRef]

7. Britvin, S.N.; Rudashevsky, N.S.; Krivovichev, S.V.; Burns, P.C.; Polekhovsky, Y.S. Allabogdanite, $(\mathrm{Fe}, \mathrm{Ni})_{2} \mathrm{P}$, a new mineral from the Onello meteorite: The occurrence and crystal structure. Am. Mineral. 2002, 87, 1245-1249. [CrossRef]

8. Britvin, S.N.; Shilovskikh, V.V.; Pagano, R.; Vlasenko, N.S.; Zaitsev, A.N.; Krzhizhanovskaya, M.G.; Lozhkin, M.S.; Zolotarev, A.A.; Gurzhiy, V.V. Allabogdanite, the high-pressure polymorph of $(\mathrm{Fe}, \mathrm{Ni})_{2} \mathrm{P}$, a stishovite-grade indicator of impact processes in the Fe-Ni-P system. Sci. Rep. 2019, 9, 1047. [CrossRef]

9. Litasov, K.D.; Ishikawa, A.; Kopylova, A.G.; Podgornykh, N.M.; Pokhilenko, N.P. Mineralogy, trace element composition, and classification of Onello high-Ni ataxite. Dokl. Earth Sci. 2019, 485, 381-385. [CrossRef]

10. Litasov, K.D.; Podgornykh, N.M. Raman spectroscopy of various phosphate minerals and occurrence of tuite in the Elga IIE iron meteorite. J. Raman Spectrosc. 2017, 48, 1518-1527. [CrossRef]

11. Plyashkevich, L.N. Some data regarding the composition and structure of the iron meteorite Elga. Meteoritika 1962, 22, 51-60. (In Russian)

12. Vronskii, V.I. On the find of the Elga iron meteorite. Meteoritika 1962, 22, 47-50. (In Russian)

13. Kvasha, L.G.; Lavrent'ev, Y.G.; Sobolev, N.V. Silicate inclusions and evidence of impact metamorphism in the Elga octahedrite. Meteoritika 1974, 33, 143-147. (In Russian)

14. Osadchii, E.G.; Baryshnikova, G.V.; Novikov, G.V. The Elga meteorite-Silicate inclusions and shock metamorphism. In Proceedings of the 12th Lunar and Planetary Science Conference, Houston, TX, USA, 16-20 March 1981; pp. 1049-1068.

15. Wasson, J.T.; Wang, J. A non-magmatic origin of group-IIE iron meteorites. Geochim. Cosmochim. Acta 1986, 50, 725-732. [CrossRef]

16. Teplyakova, S.N. Evolution of molten material in iron cores of small planets. Solar Syst. Res. 2011, 45, 515-522. [CrossRef]

17. Khisina, N.R.; Teplyakova, S.N.; Wirth, R.; Senin, V.G.; Averin, A.A.; Shiryaev, A.A. Carbon-bearing phases in shock-induced melt zones of the Elga meteorite. Geochem. Int. 2017, 55, 317-329. [CrossRef]

18. Teplyakova, S.N.; Lorenz, C.A.; Ivanova, M.A.; Kononkova, N.N.; Anosova, M.O.; Ryazantsev, K.M.; Kostitsyn, Y.A. Mineralogy of silicate inclusions in the Elga IIE iron meteorite. Geochem. Int. 2018, 56, 1-23. [CrossRef] 
19. Stewart, A.J.; Schmidt, M.W. Sulfur and phosphorus in the Earth's core: The Fe-P-S system at 23 GPa. Geophys. Res. Lett. 2007, 34, L13201. [CrossRef]

20. Gu, T.; Fei, Y.; Wu, X.; Qin, S. Phase stabilities and spin transitions of $\mathrm{Fe}_{3}\left(\mathrm{~S}_{1-\mathrm{x}} \mathrm{P}_{\mathrm{x}}\right)$ at high pressure and its implications in meteorites. Am. Mineral. 2016, 101, 205-210. [CrossRef]

21. Lavrent'ev, Y.G.; Karmanov, N.S.; Usova, L.V. Electron probe microanalysis of minerals: Microanalyzer or scanning electron microscope? Russ. Geol. Geophys. 2015, 56, 1154-1161. [CrossRef]

22. Shatskiy, A.; Gavryushkin, P.N.; Sharygin, I.S.; Litasov, K.D.; Kupriyanov, I.N.; Higo, Y.; Borzdov, Y.M.; Funakoshi, K.; Palyanov, Y.N.; Ohtani, E. Melting and subsolidus phase relations in the system $\mathrm{Na}_{2} \mathrm{CO}_{3}-\mathrm{MgCO}_{3} \pm \mathrm{H}_{2} \mathrm{O}$ at $6 \mathrm{GPa}$ and the stability of $\mathrm{Na}_{2} \mathrm{Mg}\left(\mathrm{CO}_{3}\right)_{2}$ in the upper mantle. Am. Mineral. 2013, 98, 2172-2182. [CrossRef]

23. Arefiev, A.V.; Shatskiy, A.; Podborodnikov, I.V.; Bekhtenova, A.; Litasov, K.D. The system $\mathrm{K}_{2} \mathrm{CO}_{3}-\mathrm{CaCO}_{3}-\mathrm{MgCO}_{3}$ at $3 \mathrm{GPa}$ : Implications for carbonatite melt compositions in the shallow continental lithosphere. Minerals 2019, 9, 296. [CrossRef]

24. Skála, R.; Císařová, I. Crystal structure of meteoritic schreibersites: Determination of absolute structure. Phys. Chem. Miner. 2005, 31, 721-732. [CrossRef]

25. Raghavan, V. The Fe-Ni-P (Iron-Nickel-Phosphorus) system. In Phase Diagrams of Ternary Iron Alloys, Indian Institute of Metals; ASM International: Calcutta, India, 1988; pp. 121-137.

26. Chabot, N.L.; Drake, M.J. Crystallization of magmatic iron meteorites: The effects of phosphorus and liquid immiscibility. Meteorit. Planet. Sci. 2000, 35, 807-816. [CrossRef]

27. Urakawa, S.; Matsubara, R.; Katsura, T.; Watanabe, T.; Kikegawa, T. Stability and bulk modulus of $\mathrm{Ni}_{3} \mathrm{~S}$, a new nickel sulfur compound, and the melting relations of the system Ni-NiS up to $10 \mathrm{GPa}$. Am. Mineral. 2011, 96, 558-565. [CrossRef]

28. Nabiei, F.; Badro, J.; Dennenwaldt, T.; Oveisi, E.; Cantoni, M.; Hébert, C.; El Goresy, A.; Barrat, J.-A.; Gillet, P. A large planetary body inferred from diamond inclusions in a ureilite meteorite. Nat. Commun. 2018, 9, 1327. [CrossRef] [PubMed]

29. Murayama, J.K.; Nakai, S.; Kato, M.; Kumazawa, M. A dense polymorph of $\mathrm{Ca}_{3}\left(\mathrm{PO}_{4}\right)_{2}$ : A high pressure phase of apatite decomposition and its geochemical significance. Phys. Earth Planet. Inter. 1986, 44, $293-303$. [CrossRef]

30. Xie, X.D.; Minitti, M.E.; Chen, M.; Mao, H.K.; Wang, D.Q.; Shu, J.F.; Fei, Y.W. Natural high-pressure polymorph of merrillite in the shock veins of the Suizhou meteorite. Geochim. Cosmochim. Acta 2002, 66, 2439-2444. [CrossRef]

31. Fei, Y.; Li, J.; Bertka, C.M.; Prewitt, C.T. Structure type and bulk modulus of $\mathrm{Fe}_{3} \mathrm{~S}$, a new iron-sulfur compound. Am. Mineral. 2000, 85, 1830-1833. [CrossRef]

32. Kamada, S.; Terasaki, H.; Ohtani, E.; Sakai, T.; Kikegawa, T.; Ohishi, Y.; Hirao, N.; Sata, N.; Kondo, T. Phase relationships of the Fe-FeS system in conditions up to the Earth's outer core. Earth Planet. Sci. Lett. 2010, 294, 94-100. [CrossRef]

33. Krot, A.N.; Keil, K.; Scott, E.R.D.; Goodrich, C.A.; Weisberg, M.K. Classification of meteorites and their genetic relationships. In Treatise on Geochemistry, 2nd ed.; Holland, H.D., Turekian, K.K., Eds.; Elsevier: Oxford, UK, 2014; Volume 1, pp. 1-63. [CrossRef]

34. Ruzicka, A. Silicate-bearing iron meteorites and their implications for the evolution of asteroidal parent bodies. Chem. der Erde 2014, 74, 3-48. [CrossRef]

35. Miyahara, M.; Ohtani, E.; El Goresy, A.; Lin, Y.; Feng, L.; Zhang, J.-C.; Gillet, P.; Nagase, T.; Muto, J.; Nishijima, M. Unique large diamonds in a ureilite from Almahata Sitta $2008 \mathrm{TC}_{3}$ asteroid. Geochim. Cosmochim. Acta 2015, 163, 14-26. [CrossRef]

(C) 2019 by the authors. Licensee MDPI, Basel, Switzerland. This article is an open access article distributed under the terms and conditions of the Creative Commons Attribution (CC BY) license (http://creativecommons.org/licenses/by/4.0/). 